\title{
Behavioural polymorphism in one of the world's largest populations of loggerhead sea turtles Caretta caretta
}

\author{
ALan F. Rees ${ }^{1}$, Salim Al Saady ${ }^{2}$, Annette C. Broderick ${ }^{1}$, Michael S. Coyne ${ }^{3}$, \\ Nancy Papathanasopoulou ${ }^{4}$, Brendan J. Godley ${ }^{1, *}$ \\ ${ }^{1}$ Marine Turtle Research Group, Centre for Ecology and Conservation, University of Exeter, Cornwall Campus, \\ Penryn TR10 9EZ, UK \\ ${ }^{2}$ Ministry of Environment and Climate Affairs, Muscat, Sultanate of Oman \\ ${ }^{3}$ SEATURTLE.org, 1 Southampton Place, Durham, North Carolina 27705, USA \\ ${ }^{4}$ PO Box 214383 Dubai, UAE
}

\begin{abstract}
To aid management and conservation of widely distributed marine vertebrate species, it is necessary to have a knowledge and understanding of their spatial ecology. We tracked 10 adult female loggerhead turtles Caretta caretta from Masirah Island, Sultanate of Oman, which hosts one of the world's largest breeding aggregations. Transmitters were specifically deployed early in the nesting season to enable tracking throughout the internesting and post-nesting habitats. Turtles displayed a dichotomy in behaviour during the internesting period, with 6 remaining close to Masirah Island and the others undertaking circuitous oceanic loops, hundreds of kilometres in length. This behaviour did not appear to be related to body size. Tracking-derived minimum clutch frequency was on average $( \pm \mathrm{SD}) 4.8 \pm 1.2$ nests $(\mathrm{n}=8$ ind.). Post-nesting migrations revealed a propensity towards long-term utilisation of oceanic habitats in the region between Socotra Island (Yemen) and the mainland of Yemen/Oman, with $76 \pm 15.4 \%$ of time spent in oceanic habitat ( $\mathrm{n}=8$ ind.). The spatial footprint of our tracked turtles was found to be far less than that of a similar number of turtles that were tagged later in the same season (from a separate unpublished study) and from long-distance returns of flipper tags. The spatial and temporal sub-structuring of the population highlights the need for more comprehensive tracking projects, with deployments across the breeding season in multiple years, in order to obtain reliable estimations of high-use foraging habitats of widely dispersed marine vertebrates. Variation in behaviour patterns suggests the need for diverse conservation measures.
\end{abstract}

KEY WORDS: Caretta caretta $\cdot$ Satellite tracking $\cdot$ Migration $\cdot$ Nesting $\cdot$ Sampling strategy $\cdot$ Oman

Resale or republication not permitted without written consent of the publisher

\section{INTRODUCTION}

Many megavertebrate taxa utilise large expanses of the marine environment, with differential spatial use according to life stage (e.g. tuna: Dickhut et al. 2009; albatrosses: Croxall et al. 2005; penguins: Jouventin et al. 1994; seals: Field et al. 2005, 2007; whales: Zerbini et al. 2006). The range of marine turtles may encompass entire ocean basins as foraging and development habitats (Bolten et al. 1998, Hays et al. 2004). This places them in contact with a wide range of spatially explicit threats such as incidental capture in marine fisheries in oceanic (Ferraroli et al. 2004, Lewison et al. 2004, Carranza et al. 2006) and coastal waters (James et al. 2005a, Peckham et al. 2008). This mandates the generation of a more effective understanding of their spatial ecology.

Flipper tagging has provided many important insights on migratory capabilities of marine turtles and point-to-point identification of long-distance movements and/or long-term residency to specific areas (Hendrickson 1958, Balazs 1976, Carr et al. 1978, 
Meylan 1995, Limpus \& Limpus 2001). However, the adoption of satellite telemetry in recent decades has revealed a wealth of hitherto unobtainable insights (Godley et al. 2008). Researchers are now able to accurately and remotely track individual turtles over many hundreds of kilometres for many months and in some cases multiple years (Broderick et al. 2007). Although sample sizes are often constrained, findings are almost instant and spatial information often surpasses that resulting from flipper tagging of hundreds or thousands of turtles over a number of years (e.g. Godley et al. 2003a, Troeng et al. 2005, and compare Margaritoulis et al. 2003 with Zbinden et al. 2008). Movement data have facilitated the questioning of existing management methods (Zbinden et al. 2007, Witt et al. 2008, Schofield et al. 2009) and suggestion of new ones (Shaver \& Rubio 2008, Shillinger et al. 2008).

Of the sea turtles, the loggerhead turtle Caretta caretta is the species for which the spatial ecology has been best elaborated. For example, neonate turtles from the NW Atlantic rookeries spend their first years in the open oceanic realm (Witherington 2002), moving within the North Atlantic Gyre (Bolten et al. 1998, Bolten 2003) before returning to the neritic coastal zone to complete their maturation (Bolten 2003, Schroeder et al. 2003). Once adult, the turtles undertake regular migrations between nesting grounds and foraging areas, which may or may not involve oceanic periods (Plotkin \& Spotila 2002, Hawkes et al. 2007). Evidence is accumulating that this life-history pattern is not so rigidly adhered to, in that ontogenetic shifts between oceanic and neritic developmental habitats may be reversible (Kamezaki \& Matsui 1997, Bolten 2003, McClellan \& Read 2007, McClellan et al. 2010) and that variation exists in behaviour during both internesting and intranesting periods (Blumenthal et al. 2006, Hawkes et al. 2006, see also Seminoff et al. 2008 and Hatase et al. 2006 for green turtles Chelonia mydas).

The loggerhead population at Masirah Island, off the coast of the Sultanate of Oman, was first researched in the 1970s and was determined to be one of the largest nesting aggregations in the world, comprising several tens of thousands of individual turtles nesting annually (Ross \& Barwani 1995). In the ensuing decades, flipper tagging has been undertaken to some extent and nesting beach surveys generated a more recent update on the population at 20000 to 40000 turtles nesting annually (Baldwin et al. 2003). However, certain key facts relevant for conservation management-internesting habitat, reproductive output and details of post nesting migrations are lacking.

In the present study we sought to gain insights into the spatial ecology of this population by equipping nesting turtles with satellite transmitters. We deliberately deployed near the beginning of the breeding season to facilitate insights into movements during their breeding season and post-nesting migration.

\section{MATERIALS AND METHODS}

Adult female turtles (turtles A to $\mathrm{J}_{\text {; }}$ see Table 1) were located on the nesting beaches of Masirah Island $\left(20.62^{\circ} \mathrm{N} 58.91^{\circ} \mathrm{E}, \mathrm{n}=8 ; 20.49^{\circ} \mathrm{N} 58.94^{\circ} \mathrm{E}, \mathrm{n}=2\right.$; Fig. 1). After completion of nesting and egg covering, turtles were equipped with Kiwisat 101 platform transmitter terminal (PTT) satellite tags (Sirtrack). All deployments were undertaken between 11 and 16 May 2006, which was early in the nesting season, shown in Ross \& Barwani (1995) as starting in April.

The precise level of nesting occurring prior to tag deployment was not available for the current season. Previous data (Ross 1979) suggest that approximately $26 \%$ of the study individuals would have nested

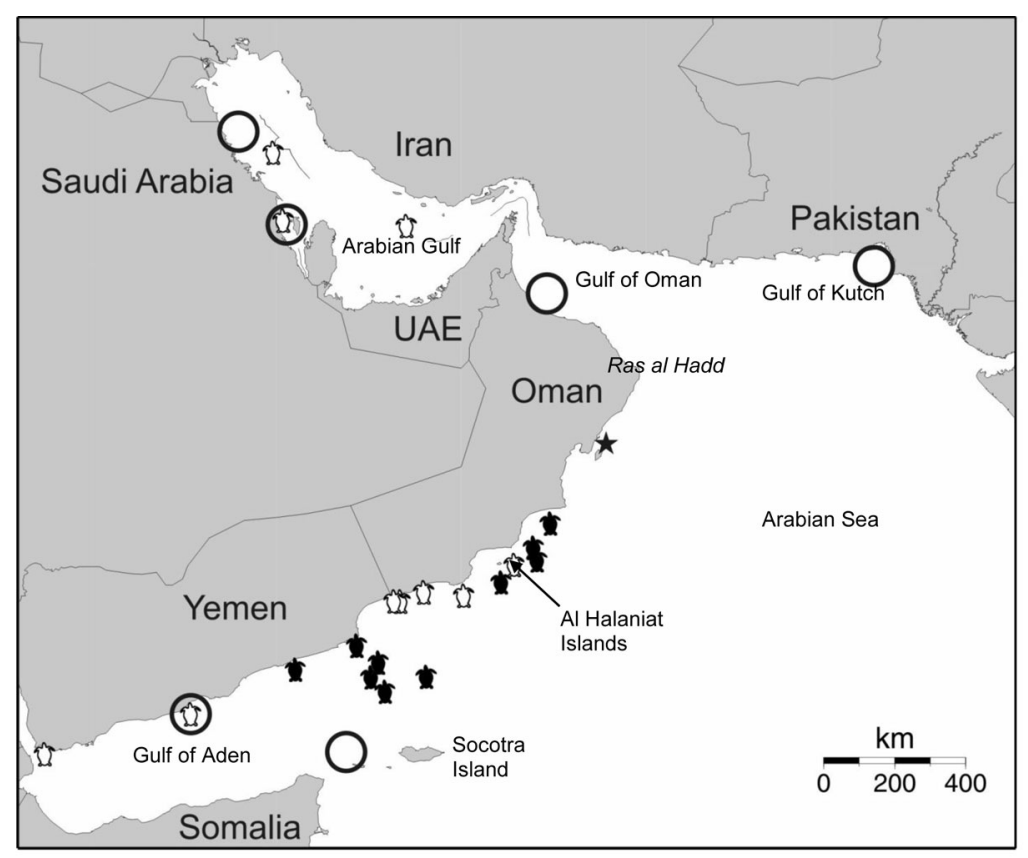

Fig. 1. Study region for Caretta caretta. $\star$ indicates tagged turtle origin (Masirah Island). indicate the end locations of turtles tracked in the present study. If indicate final locations of a further 10 transmitters placed on loggerheads at Masirah, August 2006 (B. E. Witherington \& E. Possardt pers. comm.). Circles indicate the locations of long-distance tag recoveries published prior to the present study; no indication of numbers given (Baldwin et al. 2003) 
once prior to instrumentation; therefore the clutchfrequency estimations derived for our study animals should be considered minima. No animals bore tags from a previous nesting season. Curved carapace length (CCL, measured from the nuchal notch to the tip of the longest marginal scute; i.e. CCLn-t from Bolten 1999) was recorded prior to transmitter deployment. Transmitters were programmed to be continuously on, with salt water switches used to inhibit signals during submergence, and were attached using 2-part epoxy resin (Foilfast, SFS Stadler; see Godley et al. 2002 for attachment methodology). Tags and epoxy were also coated with antifouling paint to minimise epibiont encrustation. The turtles were additionally flipper-tagged to facilitate re-identification following possible loss of the transmitter.

Telemetry data were generated utilising the Argos data collection system (CLS 2007) that were subsequently retrieved, managed and manipulated through the Satellite Tracking and Analysis Tool (STAT; details of this system are reported in Coyne \& Godley 2005).

Locations that were used for assessing movements were taken from Argos Location Classes 3, 2, 1, A and $\mathrm{B}$ (shown to be the most accurate locations; Witt et al. 2010) and filtered to remove locations which required unlikely swimming speeds $\left(5 \mathrm{~km} \mathrm{~h}^{-1}\right.$; see Luschi et al. 1998), turning behaviour $\left(<25^{\circ}\right.$ turn angle) or were inland ( $1 \mathrm{~m}$ above sea level). Locations were then interpolated to provide a single location per $24 \mathrm{~h}$ period. No interpolation was undertaken for days where no locations were received.

To facilitate comparison, data for nesting activity assessment were filtered as per Tucker (2010) and nesting was inferred from evaluating 6 of the 8 criteria used by that author; namely (1) distance criterion from a nearest coastline of $1 \mathrm{~km}$, (2) temporal criterion of emergences coinciding within the expected internesting intervals for loggerheads, (3) behavioural criterion for the turtle movements directed onshore for nesting followed by an immediate offshore departure, (4) depth criterion for bathymetry locations associated with depths of -0.5 to $0.5 \mathrm{~m}$ indicating time ashore, (5) location quality criterion for an improvement in multiple Argos Location Classes 2 or 3 within a short time span, and (6) signal frequency criterion for evidence of an increased surface interval in the PTT data. Logistical limitations meant that the final 2 criteria of Tucker (2010), ground truthing and genetic verification, were not possible.

Using the above criteria we were unable to distinguish, with any certainty, non-nesting from nesting emergences. Consequently, internesting periods determined here equate to 'egg-laying to egg-laying'. These may be several days longer than the 'egglaying to next emergence' period, defined by Limpus
(1985) and shown to have a temperature-dependent relationship (Hays et al. 2002a), for turtles that required attempts over several nights to successfully deposit a clutch.

Two distinct behaviours were identified with regards to movements and habitat use during the internesting period: sedentary or wide-ranging. We defined as wide-ranging those turtles whose maximum displacement was $>50 \mathrm{~km}$ from their initial nesting site during the internesting period. Those not displaying this behaviour were termed sedentary.

\section{RESULTS}

\section{Internesting movements}

Overall transmitter performance compared well with other studies of conspecifics. Mean \pm SD duration of tracking, from release to last transmission, was $266 \pm$ 153 d (range: 84 to 665 d). Transmitter duration was sufficient to encompass part of each animal's nesting period and at least provide indications as to patterns of post-nesting dispersal and foraging habitats of all individuals. Transmitters on 2 turtles (turtles B and C) temporarily ceased to function during their internesting periods but resumed functionality (after 47 and $70 \mathrm{~d}$ respectively) when the turtles were distant from Masirah Island and did not return. These turtles are excluded from analysis of clutch-frequency values. A further transmitter (turtle I) temporarily ceased to function after $398 \mathrm{~d}$ and resumed transmissions after $112 \mathrm{~d}$ for an additional $154 \mathrm{~d}$.

Six of the 10 turtles (turtles A to E and J) were classed as sedentary for their entire internesting periods. They remained in shallow water, averaging $<10 \mathrm{~m}$ deep, with maximum displacement from point of deployment ranging from 9.1 to $42.3 \mathrm{~km}$ (Table 1, Fig. 2).

The remaining 4 turtles (turtles F, G, H and I) were classed as wide-ranging, undertaking circuitous movements away from the island to the northeast, following local sea currents, roughly parallel to the coastline of the Omani mainland to maximal displacement of 61 to $317 \mathrm{~km}$ (Table 1, Fig. 2). All but 1 of these wideranging turtles spent all of their time in waters averaging 29 to $51 \mathrm{~m}$ deep (Table 1) in which it might be possible to feed benthically (Hawkes et al. 2006, Hatase et al. 2007). However, the most wide-ranging of the turtles ranged into waters $>3 \mathrm{~km}$ deep, averaging $>1200 \mathrm{~m}$ in depth. Turtles $\mathrm{F}$ and $\mathrm{G}$ switched to sedentary behaviour for a single internesting period after the 5th and 3rd clutches, respectively. All turtles remained in the territorial waters of Oman during the internesting period. 


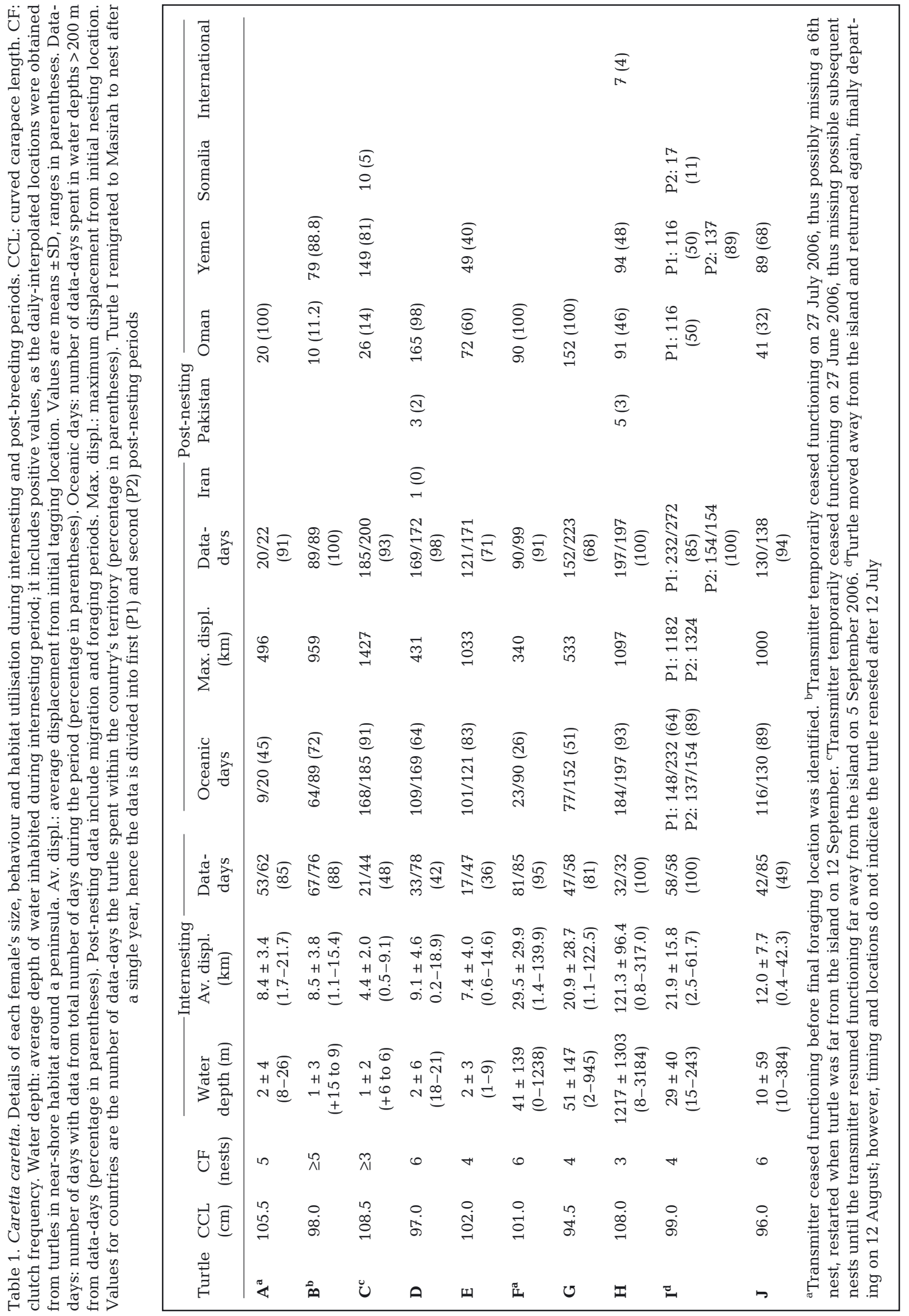




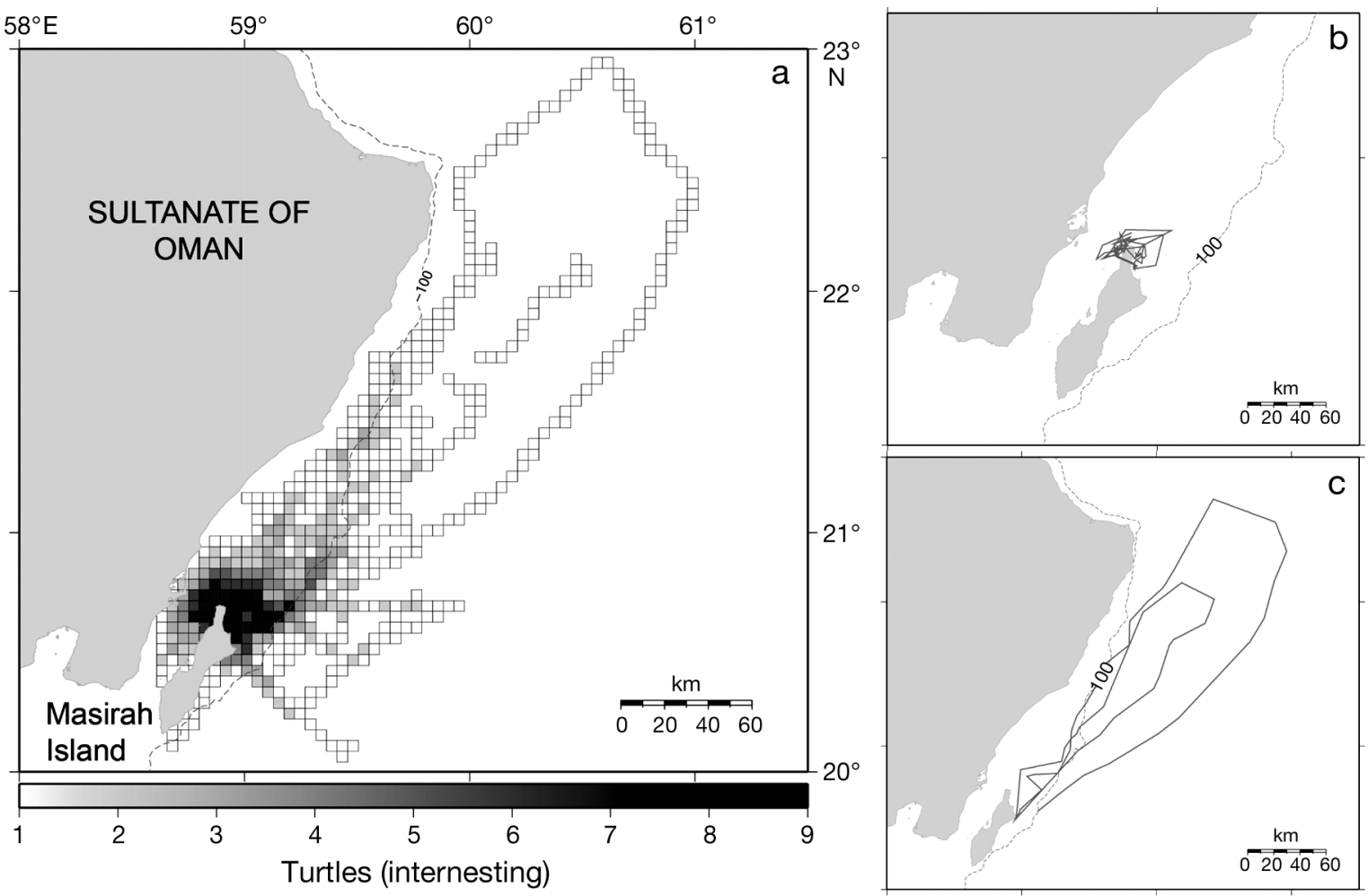

Fig. 2. Caretta caretta. Internesting period habitat ranges for 10 loggerhead turtles equipped with satellite transmitters early in the 2006 nesting season on Masirah Island. (a) Raster showing number of turtles that had passed through each location during the internesting period. (b) Example track for 'sedentary' internesting behaviour (turtle A). (c) The most wide-ranging track (turtle H). Each map shows the $100 \mathrm{~m}$ isobath. Raster shows $5 \mathrm{~km}$ grid cells and locations were determined using the filtering regime given in 'Materials and methods', except that a $1 \mathrm{~h}$ interpolation interval was used

\section{Estimating internesting interval and clutch frequency}

Time-depth recorder studies have shown that sea turtles become more active in the few days before a subsequent nesting event (e.g. Houghton et al. 2002). Increased surface time during this period raises the likelihood of the orbiting Argos satellites receiving uplinks from the transmitters. Coupling this with possible multi-night nesting activity made precise identification of individual nesting events difficult. However, close examination of the data enabled us to determine individual periods of nesting activity with some confidence (Fig. S1 in Supplement 1 at www.intres.com/articles/suppl/m418p201_supp.pdf) and calculate a mean $( \pm \mathrm{SD})$ time between nesting (internesting interval) of $16.4 \pm 1.7 \mathrm{~d}$ (range: 13 to $20 \mathrm{~d}, \mathrm{n}=36$ from all 10 ind.), which is in accordance with conspecifics elsewhere (Miller 1997).

Mean $( \pm \mathrm{SD})$ minimum clutch frequency for the 8 animals for which we have complete tracking records was $4.8 \pm 1.2$ nests (range: 3 to 6 nests; Table 1). Mean $( \pm \mathrm{SD}) \mathrm{CCL}$ for the sampled turtles was $101.0 \pm 5.0 \mathrm{~cm}$ (range: 94.5 to $108.5 \mathrm{~cm}, \mathrm{n}=10$; Table 1 ). There was no difference in carapace size between wide-ranging and sedentary individuals (Mann-Whitney $U=11$, $\mathrm{p}=0.91$; Table 1) and no significant difference was found between the internesting behavioural groups in relation to minimum clutch frequency (Mann-Whitney $U=4, \mathrm{p}=0.35$ ). No significant correlation was found between carapace length and clutch frequency (Spearman's $\left.r_{S}=-0.40, n=8, p=0.33\right)$.

\section{Post-nesting migrations}

Post-nesting migrations of the 8 turtles which were tracked to a foraging area for 89 to $197 \mathrm{~d}$ spanned the whole Indian Ocean coast of Oman, the easterly waters of Yemen and the oceanic area north of Socotra Island (Yemen). There was, however, variation in the patterns of movement shown (Video S1 in Supplement 2 at www.int-res.com/articles/suppl/m418p201_supp/).

Individual animals displayed combinations of behavioural modes described by Godley et al. (2008). Eight turtles (turtles B to E and G to J) combined migration to neritic foraging areas (type A1 behaviour) with extended periods in oceanic waters (type B behaviour). One turtle 
initially remained near Masirah before migrating southwards, but the transmissions ceased before final foraging habitat was determined (turtle F). Transmission for the final turtle (turtle A) ceased early into its southward migration; hence all turtle tracks ended south of Masirah, with 6 turtles entering territorial waters of Yemen, undertaking large-scale oceanic loops north of Socotra Island (Video S1). However, turtles D and H initially migrated north, circling the oceanic waters off Ras Al Hadd (Oman) (Table 1, Fig. 3). Further descriptions and figures of individual turtle routes can be found in Fig. S2 in Supplement 1 at www.int-res.com/articles/suppl/ m418p201_supp.pdf).

High-use areas defined by residence time and number of turtles occupying the location clearly show 2 hotspots. The first was focused along the wide continental shelf of Oman, between 17.5 and $21.5^{\circ} \mathrm{N}$, and the second was an extensive oceanic area north of Socotra Island (Fig. 4) spanning the waters of Oman and Yemen, with the latter area showing a denser utilisation.

Omitting turtles A and $\mathrm{F}$, for which final destinations were not determined, we found that there was no sig- nificant relationship (Mann-Whitney $U=21, \mathrm{p}=0.77$ ) between internesting behaviour and maximum displacement from nesting area, and a positive but nonsignificant (Spearman's $\mathrm{r}_{\mathrm{S}}=0.70, \mathrm{n}=8, \mathrm{p}=0.056$ ) relationship between turtle size and proportion of time spent in waters $>200 \mathrm{~m}$ deep, with a suggestion that the largest turtles are resident in oceanic waters for a greater proportion of time.

The longest tracking duration (turtle I) exceeded 22 mo and in this period the turtle demonstrated several important life-history traits including remigration with a 1 yr remigration interval. The turtle initially migrated to the region north of Socotra Island, displaying both type A1 and B behaviours (P1 in Table 1) until it migrated towards Masirah Island, reaching there in mid-May the following year. She remained close to the island for almost a month, when she appears to have nested twice, before transmissions ceased. After $112 \mathrm{~d}$ without signals, transmitter activity resumed, showing the turtle to have returned to the north of Socotra Island, undertaking large-scale looping movements in the area once more, almost exclusively in oceanic waters (P2 in Table 1).
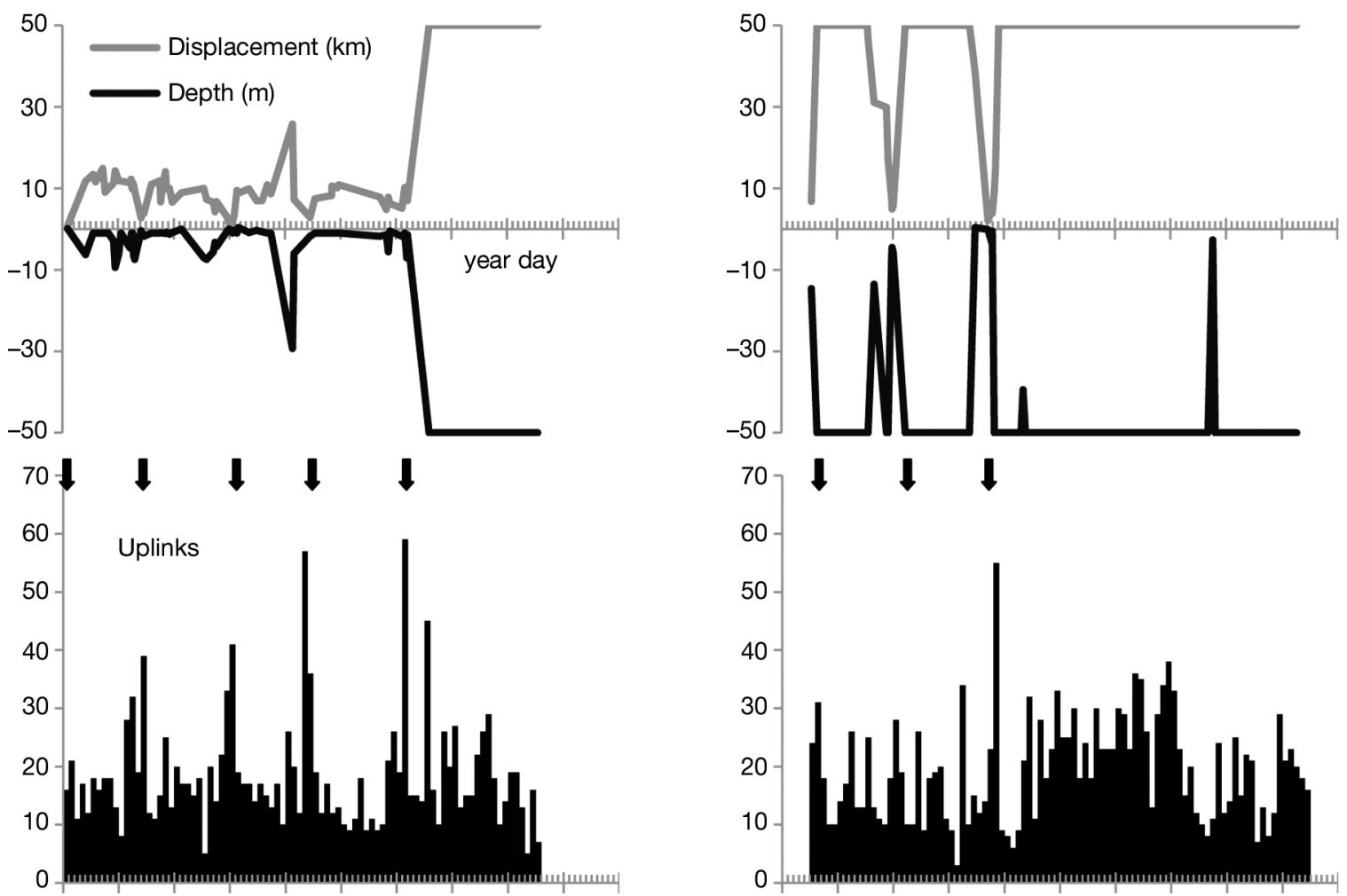

Fig. 3. Caretta caretta. Examples of data acquired during the internesting period for sedentary turtle A (left) and wide-ranging turtle $\mathrm{H}$ (right). Fidelity to nesting location is shown by water depth and displacement at near-zero. Data are synchronised at approx. 2-wk intervals. The increased activity and on-land time during nesting is generally represented in peaks in daily number of uplinks received by the Argos satellite system shown in the lower graphs. Arrows indicate inferred nesting activity. Depth and displacement are shown with values of -50 or 50 where these values were exceeded. Each tick on x-axes represents 1 day. Similar charts for all turtles are presented in Fig. S1 in Supplement 1 at www.int-res.com/articles/suppl/m418p201_supp.pdf 

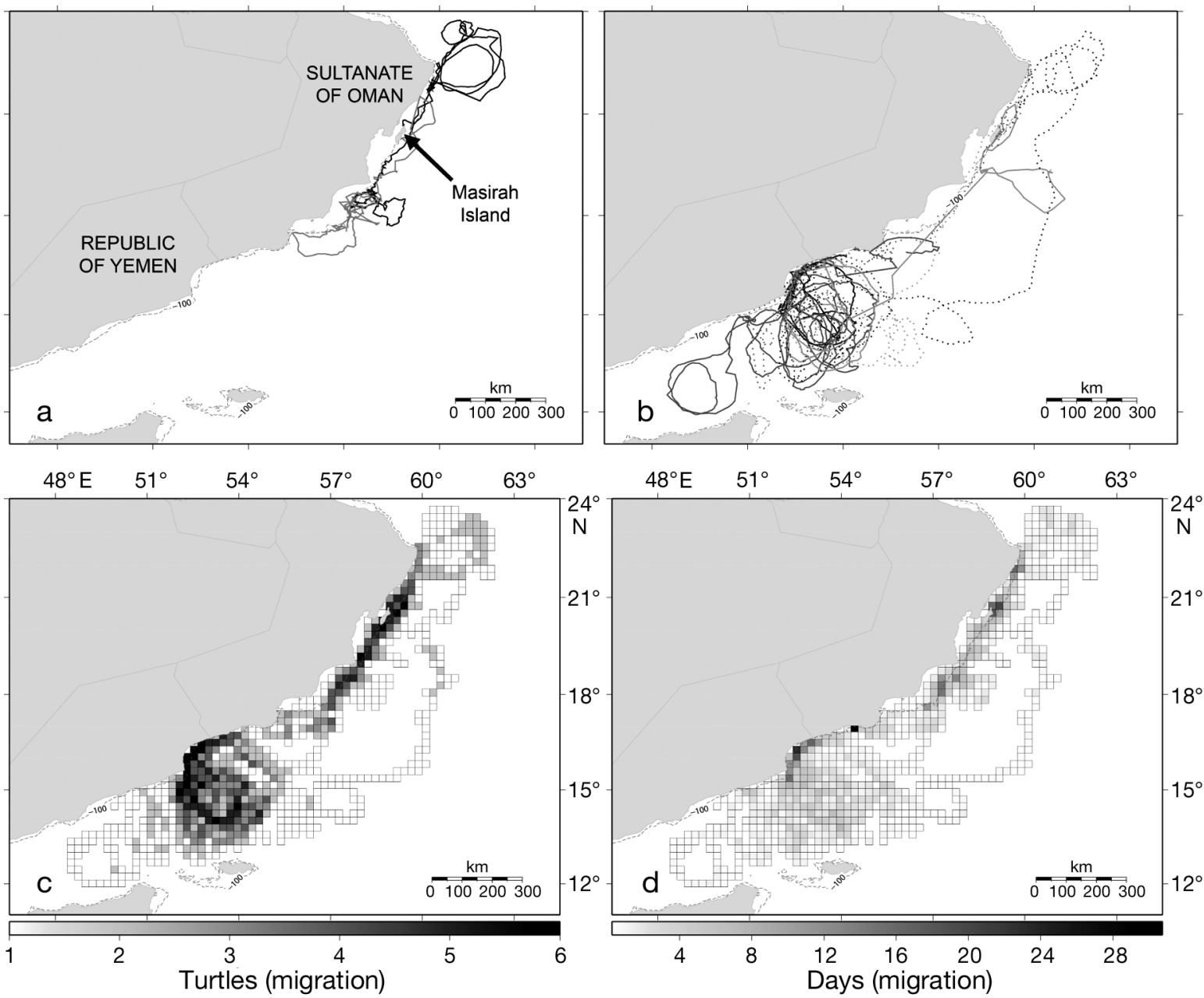

Fig. 4. Caretta caretta. Post-nesting spatial utilisation of the 10 turtles tracked. (a) Movements of 2 turtles (D and G) which, despite lengthy tracking ( $>250 \mathrm{~d}$ ), did not migrate into Yemeni waters. (b) The other 6 turtles $(\mathrm{B}, \mathrm{C}, \mathrm{E}, \mathrm{H}, \mathrm{I}$ and J) for which extensive post-nesting movements were obtained. (c) Total number of turtles having passed through a location. (d) Sum of number of days turtles were in each location. See Fig. 1 for additional geographic locations. Rasters show $25 \mathrm{~km}$ grid cells and locations were determined using the filtering regime given in 'Materials and methods', except that a $6 \mathrm{~h}$ interpolation interval was used. See Fig. S2 in Supplement 1 at www.int-res.com/articles/suppl/m418p201_supp.pdf for post-nesting tracks of individual turtles

\section{DISCUSSION}

Depending on species, marine turtles display highly variable levels of ontogenetic shift in habitat selection. Juveniles of most species live in oceanic conditions (Bjorndal 1997) and the leatherback turtle Dermochelys coriacea shows least shift, with adults remaining in oceanic waters to feed mainly on gelatinous plankton (Hays et al. 2004). Some hard-shelled species (e.g. hawksbill turtles Eretmochelys imbricata and green turtles Chelonia mydas) generally change to become inhabitants of shallow, coastal environments and feed on benthos as adults (Bjorndal 1997). The olive ridley turtle Lepidochelys olivacea is a generalist exhibiting a somewhat intermediary behaviour — with adults capable of foraging benthically in relatively deep neritic water (McMahon et al. 2007) - but is shown to also inhabit shallow coastal and the open oceanic environment (Polovina et al. 2004, Whiting et al. 2007).

Although there are exceptions (McClellan \& Read 2007, McClellan et al. 2010), juvenile loggerhead turtles undergo an ontogenetic shift in habitat use as they mature and grow, moving from oceanic to neritic waters. This is thought to be explained by higher growth rates prevalent in neritic conditions (Bolten 2003) due to increased availability of food (Snover 2008). Thus, post-nesting migrations normally terminate at neritic foraging habitats (Papi et al. 1997, Godley et al. 2003b, Schroeder et al. 2003, Hawkes et al. 2007, Zbinden et al. 2008). Recently, a dichotomy in behaviour for adult female loggerheads has been identified during post-breeding migrations and resi- 
dencies from Cape Verde, West Africa (Hawkes et al. 2006) and Japan (Hatase et al. 2002, 2007). In both cases smaller turtles used oceanic habitats with the more usual neritic habitats only used by larger individuals.

In contrast, most of the turtles in the present study extensively used pelagic habitats in addition to coastal neritic ones during the post-nesting phase, with the largest individuals mostly utilising the oceanic realm. We suggest that a polymodal foraging strategy for individuals is widespread in this population; this was recently suggested at population level for loggerheads breeding in southeastern USA (Reich et al. 2010). Additionally it should be noted that sizes of all turtles in the present study were equivalent to the larger neritic dwelling individuals from Cape Verde (Hawkes et al. 2006). We suggest that oceanic foraging may be equally if not more beneficial in energetic terms as neritic foraging in the Arabian Sea region. The lack of strong size differentiation between neritic and oceanic-dwelling individuals has also been shown in green turtles (Hatase et al. 2006, Seminoff et al. 2008).

The spatial footprint of the turtles tagged in the present study ranged from northeast Oman to the entrance to the Gulf of Aden, with maximum migratory distances from the nesting region ranging from approximately 400 to $1400 \mathrm{~km}$. Turtles tagged and tracked at Masirah Island later in the same season as part of a separate study also utilised the core foraging area, above Socotra Island, but half the individuals either progressed further southwest into the Gulf of Aden or north and west into the Arabian Gulf (Fig. 1, B. E. Witherington \& E. Possardt pers. comm.). Limpus (1985) found that loggerheads from different foraging areas in Australia begin migrations to a single nesting area at different times. Therefore there may be intraseasonal temporal sub-structuring of the population, leading the cohorts to experience diverse threats, separated both spatially and temporally.

Furthermore, long-distance recoveries of loggerhead turtles tagged on Masirah Island have been reported by Baldwin et al. (2003) (see Fig. 1). They indicate that turtles travelled south and west to the Gulf of Aden, north and northwest to the Gulf of Oman and the Arabian Gulf and additionally to the northeast to Pakistan or the Gulf of Kutch. Our present study and the other telemetry results broadly concur with this distribution. However, both satellite-tracking studies lack turtles that migrated across the Arabian Sea to the Indian subcontinent. The significance of this omission needs be determined. It may be that dispersal to this region is rare or it is only demonstrated by mid-season turtles or those from a different year-cohort not yet tracked.
Some seminal sea-turtle satellite-tracking studies (e.g. Hays et al. 1991) noted the utility of satellite tracking for deriving clutch-frequency estimations. However, as the technique became more widespread, a shift in emphasis on examining post-nesting migrations occurred (e.g. Luschi et al. 1998, Godley et al. 2002, Hays et al. 2002b). Many studies then focused on end-of-season deployment to avoid dangers to the transmitter in the internesting environment (e.g. cleaning behaviour in Schofield et al. 2006). Their findings may present a biased representation of the true spread of post-nesting movements for the population as a whole, as suggested here. This bias may be exacerbated with results obtained from a single nesting season, strongly suggesting that to obtain a full representation of a population, both intra-seasonal temporal spread and multi-annual telemetry need to be undertaken, as demonstrated by Whiting et al. (2007) and indicated by Shillinger et al. (2010). This flags the necessity for existing studies of marine turtles and other megafauna to be revisited to determine if suitable spread of sampling has been achieved to substantiate the inferences made.

The results of the present study also identify plasticity in behaviour during the breeding season. No link between body size and behaviour was established and some individuals carried out coastal sedentary and wider-ranging movements involving oceanic looping. This is the third population of loggerheads, in addition to those of Japan (Sakamoto et al. 1990) and the Cayman Islands (Blumenthal et al. 2006), in which individuals demonstrate oceanic habitat utilisation during internesting periods, contrasting with other populations (e.g. Greece: Zbinden et al. 2007; Cyprus: Fuller et al. 2008; USA: Stoneburner 1982, Plotkin \& Spotila 2002; Australia: Tucker et al. 1996) and further highlights the highly plastic behaviour of this species. We would note, however, that in a recent study of 12 loggerhead turtles in the USA (Hawkes et al. 2007), one female spent at least some time in oceanic habitats before returning to neritic habitats. Thus, as our knowledge base expands it is likely that we will discover that multiple behavioural strategies are employed in other populations previously thought to conform to the typical model.

Female loggerhead turtles typically have 2.5 to 3 yr remigration intervals between breeding years (Schroeder et al. 2003); however, evidence is accumulating for the common occurrence of single-year remigrations from flipper-tag returns (Broderick et al. 2001, Schroeder et al. 2003) and using satellite tracking (Cape Verde: B. J. Godley et al. unpubl.; Cayman Islands: Blumenthal et al. 2006). We confirm, as previously reported (Ross 1979), that single-year remigrations occur within the Masirah population at an un- 
quantified level, which has implications for population modelling requiring accurate fertility and migration rates to produce meaningful population estimates (Hays 2000, Heppell et al. 2003).

High levels of fidelity to nesting beaches, as displayed by turtle I, are well documented and established (see Schroeder et al. 2003); however, overwintering-site fidelity is less well published. Broderick et al. (2007) showed that both loggerhead and green turtles from northern Cyprus returned to the same overwintering areas after successive breeding years. Limpus \& Limpus (2003) had previously suggested that, for loggerhead turtles, the adults forage in the same areas as they grew to maturity. The propensity for foraging-site fidelity, albeit in this case a large and mainly oceanic area, is corroborated through the movements of turtle I in the present study. If this oceanic region is also the developmental habitat for the nesting population of Masirah then we can expect the at-sea population in the area to number tens of thousands. In identifying and describing the key foraging habitat for this globally significant population, we have contributed to one of the global research priorities for marine turtles (Hamann et al. 2010).

Accurate estimation of clutch frequency with appropriate error statistics is very important for estimating population size (Schroeder et al. 2003). Satellite tracking has recently been shown to provide accurate clutch-frequency counts for loggerheads in Florida (Tucker 2010), with a higher-than-previously estimated clutch frequency generated. Interpretation of tracking data was simpler for that study site, along a barrier island, in comparison with locations based around the head of a peninsula on an offshore island such as Masirah. However, technological advances in satellite tracking and data relay through the Argos system could still further improve assessments of clutch frequency. Advances include the use of haulout times, demonstrated for leatherback turtles (Georges et al. 2007) and olive ridley turtles (Hamel et al. 2008), and GPS positioning, which is more accurate than the standard Argos system (Witt et al. 2010). It has been shown that a loggerhead population of small individuals becomes resource-limited after 4 clutches in a single season (Broderick et al. 2003), whereas larger turtles may deposit more (Tucker 2010; the present study). Despite this, the current clutch-frequency estimate (mean minimum: 4.8 nests) is higher than that used in previous populationestimate calculations and hence would significantly reduce estimates that incorporate this datum (e.g. Baldwin et al. 2003). It is clear that although the loggerhead population at Masirah Island is undoubtedly one of the world's largest, more up-to-date and extensive data are required to produce a current population estimate and systematic annual surveying is necessary to identify any possible trend in population size.

The present study indicates that individual, earlynesting turtles remain in the Masirah region for nesting for a conservative average of $63 \mathrm{~d}$ (range: 32 to $85 \mathrm{~d}$ ), with some turtles remaining for a period after their nesting season. This does not include the prenesting period during which the turtles congregate near the nesting beach (Miller 1997). If we assume this length of residency also applies to later-nesting turtles (nesting occurs April through September; Ross \& Barwani 1995), we can infer that the Omani seas around Masirah and further north will be densely populated by reproductively active females and males for 6 full months of every year. This intensive habitat use should be a stimulus for at-sea studies and conservation measures to be adopted by the authorities. Additionally, Masirah hosts nesting populations of 3 other sea-turtle species whose nesting seasons fall outside that of the loggerhead's (olive ridley turtles and hawksbill turtles: Ross \& Barwani 1995, Rees \& Baker 2006; green turtles: Ross \& Barwani 1995) from which we can infer that the seas around Masirah are of year-round importance for adult marine turtles.

In Oman, loggerhead turtles are reportedly not targeted for capture by fishermen to the same extent as green turtles (Baldwin \& Al-Kiyumi 1999) and therefore directed take may not significantly impact on the population. However, with high-use locations covering large-scale oceanic habitats both for the inter- and intra-nesting period, the population is susceptible to the negative impacts of incidental capture in fisheries targeting other species. Trawling activities in Oman have been shown to negatively affect turtle populations, with an estimated mortality rate of $50 \%$ for incidentally caught specimens (Hare 1991). Lewison \& Crowder (2007) suggest that fisheries possibly have a large, albeit largely unquantified impact on loggerhead turtle populations.

A loosely coastal migratory corridor heading southwest from Masirah has been determined together with extensive foraging habitats, both neritic and oceanic, between Socotra Island and the mainland. The predictability of large numbers of loggerhead turtles in the region supports further investigations on the impacts of fishing on the population and highlights the need for joint conservation initiatives between the Sultanate of Oman and the Republic of Yemen. Such actions could protect upwards of $50 \%$ of the adult population based on the current findings.

We now have an idea as to the spatial extent of adult females from this rookery, but do not yet have any indication as to the key areas for males. It appears that in multiple species, including loggerhead turtles, males 
generally display migration patterns broadly similar to those observed in adult female conspecifics (Plotkin et al. 1996, Sakamoto et al. 1997, Hays et al. 2001, James et al. 2005a,b,c, Shaver et al. 2005). However, for hawksbill turtles, male patterns have been shown to be different to those of adult females from the same population (Van Dam et al. 2008).

Our findings covering plasticity of behaviour during the breeding season and temporal differences in dispersal from the nesting area for this globally significant population of loggerhead turtles have implications on conservation policy and management at a national and international level. We have suggested areas that should be the focus for further study, possibly to allow establishment of protected areas or other mitigation strategies (Grantham et al. 2008, Howell et al. 2008). In turn these measures need to be assessed in the context of other regional biodiversity, which includes populations of other marine turtle species. Furthermore, the spatial and temporal substructuring of the population highlights the need for more comprehensive tracking projects, with deployments across the breeding season in multiple years, in order to obtain reliable estimations for high-use foraging habitats of widely dispersed marine vertebrates.

Acknowledgements. The project was funded by the TOTAL Corporation: Foundation for Biodiversity and the Sea and TOTAL SA: Muscat Branch. B.J.G. and A.C.B. are funded by the Darwin Initiative, NERC (Natural Environment Research Council), SWRDA (South West of England Regional Development Agency) and the European Social Fund. We thank Khamis Al Farsi, and the wildlife rangers of Masirah for their assistance and support during the fieldwork. We also thank the 5 anonymous reviewers whose recommendations and comments allowed us to enhance the original manuscript.

\section{LITERATURE CITED}

Balazs GH (1976) Green turtle migrations in the Hawaiian archipelago. Biol Conserv 9:125-140

Baldwin RM, Al-Kiyumi A (1999) The ecology and conservation status of the sea turtles of Oman. In: Fisher M, Ghazanfar S, Spalton A (eds) The natural history of Oman: a Festschrift for Michael Gallagher. Backhuys Publishers, Leiden, p 89-98

Baldwin R, Hughes GR, Prince RIT (2003) Loggerhead turtles in the Indian Ocean. In: Bolten AB, Witherington BE (eds) Loggerhead sea turtles. Smithsonian Books, Washington, DC, $p$ 218-232

Bjorndal KA (1997) Foraging ecology and nutrition of sea turtles. In: Lutz PL, Musick JA (eds) The biology of sea turtles. CRC Press, Boca Raton, FL, p 199-232

Blumenthal JM, Solomon JL, Bell CD, Austin TJ and others (2006) Satellite tracking highlights the need for international cooperation in marine turtle management. Endang Spec Res 2:51-61

Bolten AB (1999) Techniques for measuring sea turtles. In: Eckert KL, Bjorndal KA, Abreu-Grobois FA, Donnelly M (eds) Research and management techniques for the con- servation of sea turtles. IUCN/SSC Mar Turtle Spec Group Publ No. 4. IUCN/SSC Marine Turtle Specialist Group, Washington, DC, p 110-114

Bolten $A B$ (2003) Active swimmers - passive drifters: the oceanic juvenile stage of loggerheads in the Atlantic System. In: Bolten AB, Witherington BE (eds) Loggerhead sea turtles. Smithsonian Books, Washington, DC, p 63-78

Bolten AB, Bjorndal KA, Martins HR, Dellinger T, Biscoito MJ, Encalada SE, Bowen BW (1998) Transatlantic developmental migrations of loggerhead sea turtles demonstrated by mtDNA sequence analysis. Ecol Appl 8:1-7

Broderick AC, Godley BJ, Hays GC (2001) Trophic status drives interannual variability in nesting numbers of marine turtles. Proc Biol Sci 268:1481-1487

Broderick AC, Glen F, Godley BJ, Hays GC (2003) Variation in reproductive output of marine turtles. J Exp Mar Biol Ecol 288:95-109

Broderick AC, Coyne MS, Fuller WJ, Glen F, Godley BJ (2007) Fidelity and overwintering of sea turtles. Proc Biol Sci 274:1533-1538

Carr AF, Carr MH, Meylan AB (1978) The ecology and migration of sea turtles, 7: the west Caribbean green turtle colony. Bull Am Mus Nat Hist 162:1-48

Carranza A, Domingo A, Estrades A (2006) Pelagic longlines: a threat to sea turtles in the Equatorial Eastern Atlantic. Biol Conserv 131:52-57

CLS (2007) ARGOS user's manual: worldwide tracking and environmental monitoring by satellite. 14 October 2008 update. Argos/CLS, Toulouse. Available at: www.argossystem.org/manual

> Coyne MS, Godley BJ (2005) Satellite Tracking and Analysis Tool (STAT): an integrated system for archiving, analyzing and mapping animal tracking data. Mar Ecol Prog Ser 301: $1-7$

Croxall JP, Silk JRD, Phillips RA, Afanasyev V, Briggs DR (2005) Global circumnavigations: tracking year-round ranges of nonbreeding albatrosses. Science 307:249-250

> Dickhut RM, Deshpande AD, Cincinelli A, Cochran MA and others (2009) Atlantic bluefin tuna (Thunnus thynnus) population dynamics delineated by organochlorine tracers. Environ Sci Technol 43:8522-8527

Ferraroli S, Georges JY, Gaspar P, Le Maho Y (2004) Endangered species: where leatherback turtles meet fisheries. Nature 429:521-522

> Field IC, Bradshaw CJA, Burton HR, Sumner MD, Hindell MA (2005) Resource partitioning through oceanic segregation of foraging juvenile southern elephant seals (Mirounga leonina). Oecologia 142:127-135

Field IC, Bradshaw CJA, Van den Hoff J, Burton HR, Hindell MA (2007) Age-related shifts in the diet composition of southern elephant seals expand overall foraging niche. Mar Biol 150:1441-1452

> Fuller WJ, Broderick AC, Phillips RA, Silk JRD, Godley BJ (2008) Utility of geolocating light loggers for indicating at-sea movements in sea turtles. Endang Species Res 4: 139-146

Georges JY, Fossette S, Billes A, Ferraroli S and others (2007) Meta-analysis of movements in Atlantic leatherback turtles during nesting season: conservation implications. Mar Ecol Prog Ser 338:225-232

Godley BJ, Richardson S, Broderick AC, Coyne MS, Glen F, Hays GC (2002) Long-term satellite telemetry of the movements and habitat utilisation by green turtles in the Mediterranean. Ecography 25:352-362

> Godley BJ, Lima EHSM, Åkesson S, Broderick AC and others (2003a) Movement patterns of green turtles in Brazilian coastal waters described by satellite tracking and flipper tagging. Mar Ecol Prog Ser 253:279-288 
Godley BJ, Broderick AC, Glen F, Hays GC (2003b) Postnesting movements and submergence patterns of loggerhead marine turtles in the Mediterranean assessed by satellite tracking. J Exp Mar Biol Ecol 287:119-134

Codley BJ, Blumenthal JM, Broderick AC, Coyne MS, Godfrey MH, Hawkes LA, Witt MJ (2008) Satellite tracking of sea turtles: Where have we been and where do we go next? Endang Species Res 4:3-22

Grantham HS, Petersen SL, Possingham HP (2008) Reducing bycatch in the South African pelagic longline fishery: the utility of different approaches to fisheries closures. Endang Species Res 5:291-299

Hamann M, Godfrey MH, Seminoff JA, Arthur K and others (2010) Global research priorities for sea turtles: informing management and conservation in the 21st century. Endang Species Res 11:245-269

Hamel MA, McMahon CR, Bradshaw CJA (2008) Flexible inter-nesting behaviour of generalist olive ridley turtles in Australia. J Exp Mar Biol Ecol 359:47-54

Hare SR (1991) Turtles caught incidental to demersal finfish fishery in Oman. Mar Turtle Newsl 53:14-16

- Hatase H, Takai N, Matsuzawa Y, Sakamoto W and others (2002) Size-related differences in feeding habitat use of adult female loggerhead turtles Caretta caretta around Japan determined by stable isotope analyses and satellite telemetry. Mar Ecol Prog Ser 233:273-281

> Hatase H, Sato K, Yamauchi M, Takahashi K, Tsukamoto K (2006) Individual variation in feeding habitat use by adult female green sea turtles (Chelonia mydas): Are they obligate herbivores? Oecologia 149:52-64

> Hatase H, Omuta K, Tsukamoto K (2007) Bottom or midwater: alternative foraging in adult female loggerhead sea turtles. J Zool (Lond) 273:46-55

Hawkes LA, Broderick AC, Coyne MS, Godfrey MH and others (2006) Phenotypically linked dichotomy in sea turtle foraging requires multiple conservation approaches. Curr Biol 16:990-995

Hawkes LA, Broderick AC, Coyne MS, Godfrey MH, Godley BJ (2007) Only some like it hot - quantifying the environmental niche of the loggerhead sea turtle. Diversity Distrib 13:447-457

Hays GC (2000) The implications of variable remigration intervals for the assessment of population size in marine turtles. J Theor Biol 206:221-227

- Hays GC, Webb PI, Hayes JP, Priede IG, French J (1991) Satellite tracking of a loggerhead turtle (Caretta caretta) in the Mediterranean. J Mar Biol Assoc UK 71:743-746

> Hays GC, Broderick AC, Glen F, Godley BJ, Nichols WJ (2001) The movements and submergence behaviour of male green turtles at Ascension Island. Mar Biol 139: 395-399

Hays GC, Broderick AC, Glen F, Godley BJ, Houghton JDR, Metcalfe JD (2002a) Water temperature and internesting intervals for loggerhead (Caretta caretta) and green (Chelonia mydas) sea turtles. J Therm Biol 27:429-432

> Hays GC, Broderick AC, Godley BJ, Lovell P, Martin C, McConnell BJ, Richardson S (2002b) Biphasal longdistance migration in sea turtles. Anim Behav 64:895-898

Hays GC, Houghton JDR, Myers AE (2004) Endangered species: pan-Atlantic leatherback turtle movements. Nature 429:522

Hendrickson JR (1958) The green turtle Chelonia mydas in Malaya and Sarawak. Proc Zool Soc Lond 130:455-535

Heppell SS, Crowder LB, Crouse DT, Epperly SP, Frazer NB (2003) Population models for Atlantic loggerheads: past, present and future. In: Bolten $A B$, Witherington BE (eds) Loggerhead sea turtles. Smithsonian Books, Washington, DC, p 255-273
> Houghton JDR, Broderick AC, Godley BJ, Metcalfe JD, Hays GC (2002) Diving behaviour during the internesting interval for loggerhead turtles Caretta caretta nesting in Cyprus. Mar Ecol Prog Ser 227:63-70

> Howell EA, Kobayashi DR, Parker DM, Balazs GH, Polovina JJ (2008) TurtleWatch: a tool to aid in the bycatch reduction of loggerhead turtles Caretta caretta in the Hawaii-based pelagic longline fishery. Endang Species Res 5: 267-278

James MC, Ottensmeyer CA, Myers RA (2005a) Identification of high-use habitat and threats to leatherback sea turtles in northern waters: new directions for conservation. Ecol Lett 8:195-201

James MC, Eckert SA, Myers RA (2005b) Migratory and reproductive movements of male leatherback turtles (Dermochelys coriacea). Mar Biol 147:845-853

> James MC, Myers RA, Ottensmeyer CA (2005c) Behaviour of leatherback sea turtles, Dermochelys coriacea, during the migratory cycle. Proc Biol Sci 272:1547-1555

> Jouventin P, Capdeville D, Cuenot-Chaillet F, Boiteau C (1994) Exploitation of pelagic resources by a non-flying seabird: satellite tracking of the king penguin throughout the breeding cycle. Mar Ecol Prog Ser 106:11-19

Kamezaki N, Matsui M (1997) Allometry in the loggerhead turtle, Caretta caretta. Chelonian Conserv Biol 2:421-425

> Lewison RL, Crowder L (2007) Putting longline bycatch of sea turtles into perspective. Conserv Biol 21:79-86

> Lewison RL, Freeman SA, Crowder L (2004) Quantifying the effects of fisheries on threatened species: the impact of pelagic longlines on loggerhead and leatherback sea turtles. Ecol Lett 7:221-231

Limpus CJ (1985) A study of the loggerhead sea turtle, Caretta caretta, in Eastern Australia. PhD thesis, University of Queensland, St. Lucia

Limpus CJ, Limpus DJ (2001) The loggerhead turtle, Caretta caretta, in Queensland: breeding migrations and fidelity to a warm temperate feeding area. Chelonian Conserv Biol 4:142-153

Limpus CJ, Limpus DJ (2003) Biology of the loggerhead turtle in Western South Pacific foraging areas. In: Bolten AB, Witherington BE (eds) Loggerhead sea turtles. Smithsonian Books, Washington, DC, p 93-113

Luschi P, Hays GC, Del Seppia C, Marsh R, Papi F (1998) The navigational feats of green sea turtles migrating from Ascension Island investigated by satellite telemetry. Proc Biol Sci 265:2279-2284

Margaritoulis D, Argano R, Baran I, Bentivegna F and others (2003) Loggerhead turtles in the Mediterranean Sea: present knowledge and conservation perspectives. In: Bolten $A B$, Witherington BE (eds) Loggerhead sea turtles. Smithsonian Books, Washington, DC, p 175-198

McClellan CM, Read AJ (2007) Complexity and variation in loggerhead sea turtle life history. Biol Lett 3:592-594

McClellan CM, Braun-McNeill J, Avens L, Wallace BP, Read AJ (2010) Stable isotopes confirm a foraging dichotomy in juvenile loggerhead sea turtles. J Exp Mar Biol Ecol 387:44-51

McMahon CR, Bradshaw CJA, Hays GC (2007) Satellite tracking reveals unusual diving characteristics for a marine reptile, the olive ridley turtle (Lepidochelys olivacea). Mar Ecol Prog Ser 329:239-252

Meylan AB (1995) Sea turtle migration-evidence from tag returns. In: Bjorndal KA (ed) Biology and conservation of sea turtles, revised edn. Smithsonian Institute Press, Washington, DC, p 91-100

Miller JD (1997) Reproduction in sea turtles. In: Lutz PL, Musick JA (eds) The biology of sea turtles. CRC Press, Boca Raton, FL, p 51-81 
Papi F, Luschi P, Crosio E, Hughes GR (1997) Satellite tracking experiments on the navigational ability and migratory behaviour of the loggerhead turtle Caretta caretta. Mar Biol 129:215-220

Peckham SH, Maldonado Diaz D, Koch V, Mancini A, Gaos A, Tinker MT, Nichols WJ (2008) High mortality of loggerhead turtles due to bycatch, human consumption and strandings at Baja California Sur, Mexico, 2003 to 2007. Endang Species Res 5:171-183

Plotkin PT, Spotila J (2002) Post-nesting migrations of loggerhead turtles Caretta caretta from Georgia, USA: conservation implications for a genetically distinct subpopulation. Oryx 36:396-399

Plotkin PT, Owens DW, Byles R, Patterson RM (1996) Departure of male olive ridley turtles (Lepidochelys olivacea) from a nearshore breeding ground. Herpetologica 52:1-7

Polovina JJ, Balazs GH, Howell EA, Parker DM, Seki MP, Dutton PH (2004) Forage and migration habitat of loggerhead (Caretta caretta) and olive ridley (Lepidochelys olivacea) sea turtles in the central North Pacific Ocean. Fish Oceanogr 13:36-51

Rees AF, Baker SL (2006) Hawksbill and olive ridley nesting on Masirah Island, Sultanate of Oman: an update. Mar Turtle Newsl 113:2-5

Reich KJ, Bjorndal KA, Frick MG, Witherington BE, Johnson C, Bolten AB (2010) Polymodal foraging in adult female loggerheads (Caretta caretta). Mar Biol 157:113-121

Ross JP (1979) Sea turtles in the Sultanate of Oman. Final project report 1320. World Wildlife Fund International, Gland, Switzerland

Ross JP, Barwani MA (1995) Review of sea turtles in the Arabian area. In: Bjorndal KA (ed) Biology and conservation of sea turtles, revised edn. Smithsonian Institute Press, Washington, DC, p 373-383

Sakamoto W, Uchida I, Naito Y, Kureha K, Tujimura M, Sato K (1990) Deep diving behaviour of the loggerhead turtle near the frontal zone. Bull Jpn Soc Sci Fish 56:1435-1443

Sakamoto W, Bando T, Arai N, Baba N (1997) Migration paths of the adult female and male loggerhead turtles Caretta caretta determined through satellite telemetry. Fish Sci 63:547-552

Schofield G, Katselidis KA, Dimopoulos P, Pantis JD, Hays GC (2006) Behaviour analysis of the loggerhead sea turtle Caretta caretta from direct in-water observation. Endang Species Res 2:71-79

Schofield G, Lilley MKS, Bishop CM, Brown P and others (2009) Conservation hotspots: implications of intense spatial area use by breeding male and female loggerheads at the Mediterranean's largest rookery. Endang Species Res 10:191-202

Schroeder BA, Foley AM, Bagley DA (2003) Nest site selection, oviposition, eggs, development, hatching and emergence of loggerhead turtles. In: Bolten $A B$, Witherington $\mathrm{BE}$ (eds) Loggerhead sea turtles. Smithsonian Books, Washington, DC, p 125-143

Seminoff JA, Zarate P, Coyne M, Foley DG, Parker D, Lyon BN, Dutton PH (2008) Post-nesting migrations of Galapagos green turtles Chelonia mydas in relation to oceanographic conditions, integrating satellite telemetry with remotely sensed ocean data. Endang Species Res 4:57-72

Shaver DJ, Rubio C (2008) Post-nesting movement of wild and head-started Kemp's ridley sea turtles Lepidochelys kem-

Editorial responsibility: Matthias Seaman,

Oldendorf/Luhe, Germany pii in the Gulf of Mexico. Endang Species Res 4:43-55

Shaver DJ, Schroeder BA, Byles RA, Burchfield PM, Pena J, Marquez R, Martinez HJ (2005) Movements and home ranges of adult male Kemp's ridley sea turtles (Lepidochelys kempii) in the Gulf of Mexico investigated by satellite telemetry. Chelonian Conserv Biol 4:817-827

Shillinger GL, Palacios DM, Bailey H, Bograd SJ and others (2008) Persistent leatherback turtle migrations present opportunities for conservation. PLoS Biol 6:e171

Shillinger GL, Swithenbank AM, Bograd SJ, Bailey H and others (2010) Identification of high-use internesting habitats for eastern Pacific leatherback turtles: role of the environment and implications for conservation. Endang Species Res 10:215-232

Snover ML (2008) Ontogenetic shifts in marine organisms: influencing factors and the impact of climate variability. Bull Mar Sci 83:53-67

> Stoneburner DL (1982) Satellite telemetry of loggerhead sea turtle movement in the Georgia Bight. Copeia 400-408

Troeng S, Evans DR, Harrison E, Lagueux CJ (2005) Migration of green turtles Chelonia mydas from Tortuguero, Costa Rica. Mar Biol 148:435-447

Tucker AD (2010) Nest site fidelity and clutch frequency of loggerhead turtles are better elucidated by satellite telemetry than by nocturnal tagging efforts: implications for stock estimation. J Exp Mar Biol Ecol 383:48-55

Tucker AD, Fitzsimmons NN, Limpus CJ (1996) Conservation implications of inter-nesting habitat use by loggerhead turtles (Caretta caretta) in Woongarra Marine Park, Queensland, Australia. Pac Conserv Biol 2:157-166

Van Dam RP, Diez CE, Balazs GH, Colon Colon LA, McMillan WO, Schroeder B (2008) Sex-specific migration patterns of hawksbill turtles breeding at Mona Island, Puerto Rico. Endang Species Res 4:85-94

Whiting SD, Long JL, Coyne M (2007) Migration routes and foraging behaviour of olive ridley turtles Lepidochelys olivacea in northern Australia. Endang Species Res 3:1-9

Witherington BE (2002) Ecology of neonate loggerhead turtles inhabiting lines of downwelling near a Gulf Stream front. Mar Biol 140:843-853

Witt MJ, Broderick AC, Coyne MS, Formia A and others (2008) Satellite tracking highlights difficulties in the design of effective protected areas for critically endangered leatherback turtles Dermochelys coriacea during the inter-nesting period. Oryx 42:296-300

Witt MJ, Åkesson S, Broderick AC, Coyne MS and others (2010) Assessing accuracy and utility of satellite-tracking data using Argos-linked Fastloc-GPS. Anim Behav 80:571-581

Zbinden J, Aebischer A, Margaritoulis D, Arlettaz R (2007) Insights into the management of sea turtle internesting area through satellite telemetry. Biol Conserv 137: $157-162$

Zbinden J, Aebischer A, Margaritoulis D, Arlettaz R (2008) Important areas at sea for adult loggerhead sea turtles in the Mediterranean Sea: satellite tracking corroborates findings from potentially biased sources. Mar Biol 153:899-906

Zerbini AN, Andriolo A, Heide-Jorgensen MP, Pizzorno JL and others (2006) Satellite-monitored movements of humpback whales Megaptera novaeangliae in the Southwest Atlantic Ocean. Mar Ecol Prog Ser 313:295-304

Submitted: March 24, 2010; Accepted: August 11, 2010

Proofs received from author(s): November 11, 2010 